\title{
Notes and Queries
}

\section{Author(s): John Lecky, Seamus O Casaide and J. C.}

Source: Kerry Archaeological Magazine, Vol. 4, No. 20 (Apr., 1918), pp. 288-292

Stable URL: http://www.jstor.org/stable/30059814

Accessed: 27-06-2016 11:05 UTC

Your use of the JSTOR archive indicates your acceptance of the Terms \& Conditions of Use, available at

http://about.jstor.org/terms

JSTOR is a not-for-profit service that helps scholars, researchers, and students discover, use, and build upon a wide range of content in a trusted digital archive. We use information technology and tools to increase productivity and facilitate new forms of scholarship. For more information about JSTOR, please contact support@jstor.org. 


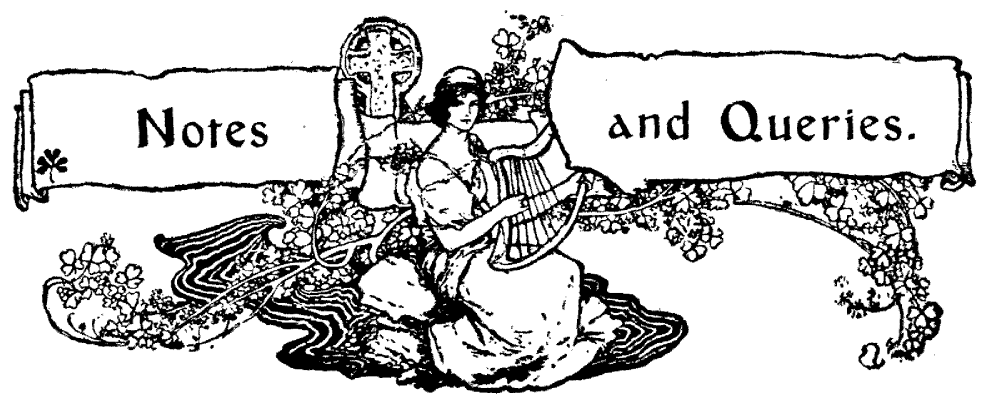

OLD CORK CLOCKS.

[With the kind permission of the Hon. Secretary of the "Cork Historical and Archæological Society" we publish the following interesting letter, dated the 10th September, 1917, from Mr. John Lecky, 17 Hazlewell Road, Putney, to the Editor of the above Society's Journal, on the subject of Dr. Longfield and his astronomical instruments, and, incidentally of some curious old clocks. This letter was published in the Cork Journal for July-September, 1917, and we have no doubt will prove of equal interest to Kerry readers.]

Dr. Longfield (mentioned in Colonel Grove White's "Historical and Topographical Notes," April-June No. of Journal, page 61) was a very scientific man and astronomer.

In the Philosophical transactions of the Royal Society, vol. 69 , pages 163 to 180 , are three letters from him to the then Astronomer Royal, Dr. Nevil Maskelyne, dated Corke, 1773 , October 1; 1774, February 18; and 1779, February 17 , in which he gives particulars of his observations for determining the latitude and longitude of Cork. In these observations he was assisted by $\mathrm{Mr}$. Mainadue and $\mathrm{Mr}$. Newenham, and there is also an accompanying note by Maskelyne on the subject.

Dr. Longfield's house was in Patrick Street, on or near the site of Messrs. Dowden's establishment, and he describes how he built a solid pier for his transit instrument, and how he adapted the upper part of the house for an observatory. He mentions his instruments: an equal altitude instrument, a quadrant of one foot radius by Bird (see later), another of French make, two and a-half feet radius, a telescope by Dolland, a parallactic instrument with a common telescope five feet long, and a reticule rhomboide, and two 
astronomical alocks. In his last letter (page 173) he gives particulars of a clock, but whether this is one of the two or a third clock does not appear (but see later).

On Dr. Longfield's death, my grandfather, John Lecky, purchased, in 1819, one of the clocks, the transit instrument, a mahogany telescope stand, and the stand of the equal altitude instrument.

The clock thus bought is by John Knapp, Corke, and is remarkable for various peculiarities of construction: one being that the hour, minute, and seconds hands all turn on the same centre, and the long arm of the seconds hand extends to the full diameter of the face. The long arm got rusted and broken off, but James Mangan, the watchmaker, of Patrick Street, made and fastened the present hand. Now comes in a further peculiarity, for it was found that the short end of the new hand was not quite heavy enough, so my grandfather put on a little piece of wood as a counterbalance, and as this was not enough my father, Robert J. Lecky, much to James Mangan's amusement, stuck in a little iron tack. My father had the clock going until his death in 1897, and then the clock, being of such interest, the authorities at the Science Museum, Kensington, were pleased to take it. In passing it to them, I expressly stipulated that: "Whatsoever King might reign or Dynasty hold sway, Sir," that piece of wood and that tack should be carefully preserved. This has been duly observed, and they are both there to this day. Was there ever a tack with such a history?

The Transit instrument by Monck my father presented to the Royal Astronomical Society, and I saw it there a few days ago. The telescope stand has always carried my grandfather's Tully telescope, and I gave both telescope and stand (with some other old instruments) to the Science Museum in 1915. They are both well housed there in a large glass case all to themselves. What became of the stand of the Equal Altitude instrument I do not know, but there is not the slightest doubt about the one-foot radius quadrant by Bird having been made for and used by Captain Cook in his famous voyage for the transit of Venus in 1769. $\mathrm{My}$ 
father knew it all his life; he finally acquired it in 1887 , and it also is now in the Science Museum. I have his notes of its history.

Of the clock specially described by Dr. Longfield (page 173), my father, writing in 1885, said that "it was for "many years the mean time clock in the observatory of the " Royal Cork Institution, South Mall, now Julian's Coach "factory, and it is now in the observatory of St. Vinoent de "Paul Community, Sunday's Well," and he also said that the Dolland telescope was in the possession of $\mathrm{Mr}$. Joseph Bennett of Blair's Castle.

I have three other old Cork clocks : one a Franklin dial, made about 1820 for Dr. Roger Dartnell of Youghal by Thomas Austen, and used by Dr. Dartnell in his observatory on the Town Wall until his death in 1832 , when it passed to my father. Another by Richard Eustace was bought by my grandfather at the time of his marriage in 1796, or soon after, and the third is by Gregory Upington. This clock belonged to my uncle, the late James Beale, but we do not know its history nor its age, but the late James Murphy wrote that Gregory Upington had a clock and watchmaker's business in the North Main Street about 1700. All those three clocks are in my house, and going well, so I think you will agree that Cork is at present well represented over here in its old clocks.

JoHN LEckY.

\section{KERRY NEWSPAPERS.}

THE old Kerry newspapers have become very scarce. Mr. E. R. McC. Dix, the leading authority on Irish bibliography, mentioned in the "Cork Archæological Journal" (1904, p. 207), that he had only traced one copy (dated 26th March, 1805) of Chute's "Western Herald." Even references in contemporary Cork, \&c., newspapers are not numerous.

The "Cork Patriot" of 8th May, 1809, quotes the "Kerry E. P.," and the "Kerry Evening Past" is also quoted by 
the "Cork Advertiser" of 21st Jan., 1808, by the "Clonmel Advertiser" of 5th Oct., 1811, by the "Waterford Mirror" of 30th Jan., 1822, and by the "Dublin Patriot" of 7th and 21st Feb., 1822.

The "Kerry Despatch" is quoted by the "Cork Advertiser" of 17th Nov., 1808, and of 19th Jan., 1809.

The "Cork Examiner" of Monday, 25th Oct., 1841, quotes the "Kerry Examiner" of Friday.

The "Kerry Herald" is quoted by the "Clonmel Advertiser" of 7th Dec., 1811, and the "Kerry Western Herald" is quoted by the "Clonmel Advertiser" of 21st Aug., 1813, and by the "Dublin Patriot" of 13th Dec., 1821, and of 14th Feb., 1822. The "Waterford Mirror" of Monday, 18th Feb., 1822, quotes the "Western Herald" (Co. Kerry) of Wednesday last. In the Cork Carnegie Library there is a single copy of an old newspaper of four folio pages (four columns to a page) the first page bearing the heading "Chute's Western Herald, or Kerry Advertiser. Vol. XVIII., No. 1776. Tralee-Monday, June 10, 1811. Price Five Pence." The other pages are headed "The Western Herald, or Kerry Advertiser." The colophon shows that the paper was "Printed every Monday and Thursday Evening, for the Proprietor, Pierce Chute, and Published on the same Days, at the Western Herald Office, Nelson Street, Tralee." Judging by the numbering of the above issue of this bi-weekly paper it would appear to have been started about May, 1794.

Apparently no attempt is being made to preserve in any Public Library in Kerry even the present-day local newspapers, which could probably be obtained for the asking.

\section{Seamus O Casaide.}

[With the above Mr. O'Casaide has forwarded a brochure entitled: "A Guide to Old Waterford Newspapers," which he has compiled, giving in a handy form very complete information about the newspapers and other literary periodicals started in that County during the last two centuries. 
It seems most desirable that some one should do the same for the Co. Kerry, where, no doubt, many old newspapers may still be found, preserved in private and public libraries or lying about elsewhere, if adequate efforts were made to hunt them up.-ED.]

\section{A FORGOTTEN KERRY BARD.}

In the "Cork Mercantile Chronicle" of Friday, March 3rd, 1820, was published the following obituary notice:- "Died in the Parish of Aiglish, in the vicinity of Killarney, at the advanced age of 115 years, Theodore O'Sullivan, the celebrated Irish Bard. This extraordinary man, who was a great composer in his native language, expired suddenly on Wednesday last (March 1st, or February 23rd?) whilst sowing oats in the field of one of his great grand-children, having retained his faculties to the last moment. He is said to have sung to the plough one of his favourite lyrics, and actually breathed his last at the final stanza of his National melody. The deceased followed the occupation of a cooper, and is said to have made a churn from which butter was taken for use at the christening of his 26 th great grand-child."

J. C.

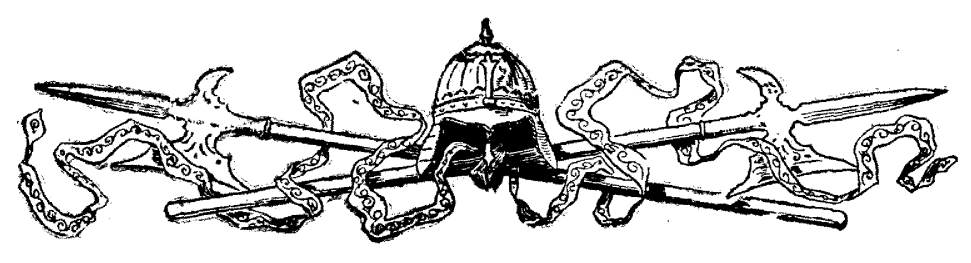

